\title{
Penerapan Kebijakan Earmarking Tax Pada Pemungutan Pajak Kendaraan Bermotor Terhadap Pembangunan Dan Pemeliharaan Jalan Di Provinsi Sulawesi Utara
}

\author{
Andre Stevan Masihor \\ Winston Pontoh \\ Program Pendidikan Profesi Akuntansi \\ Fakultas Ekonomi dan Bisnis \\ Universitas Sam Ratulangi \\ Email: masihorandre@gmail.com
}

\begin{abstract}
Regional autonomy and decentralization setting authority for every area in their independence and realize the potential to improve people's welfare. One potential area that is growing is a local tax, which is currently setting based on Undang-undang No. 28 tahun 2009. In terms of social welfare legislation is mandated to allocate some funds for the construction sector activities withholding tax, this policy is known as earmarking tax. Motor vehicle tax is one tax that is included in this policy where the amount of the allocation that is at least $10 \%$ of the proceeds and used for the construction of transportation infrastructure. In SULUT terms are defined in Perda No. 7 tahun 2011 in which the contents of its mandate in accordance with such provisions. The purpose of this study is to analyze the implementation of earmarking tax policy of motor vehicle tax in the province of North Sulawesi in accordance with the mandate of the legislation in force. The analytical method used is descriptive analysis. The findings of this study are earmarking tax policy in SULUT go hand in hand with SULUT budget system where revenues and expenditures through the general treasury area. In 2014 the expenditure for the improvement of road infrastructure facilities reached $97.96 \%$ of total motor vehicle tax in North Sulawesi, thus setting the tax earmarking in SULUT not in accordance with applicable regulations.
\end{abstract}

\section{Keyword : Earmarking Tax, Motor Vehicle Tax}

\section{PENDAHULUAN}

Otonomi daerah dan desentralisasi merupakan kebijakan pemerintah yang memberikan yang memberi kewenangan bagi masing-masing daerah dalam hal kemandiriannya untuk mengatur pemerintahannya untuk terwujudnya kesejahteraan rakyat serta mengoptimalkan potensi masing-masing khususnya Pendapatan Asli Daerah (PAD). selain PAD daerah juga harus mengatur pemerintahannya untuk terwujudnya kesejahteraan rakyat.

Pendapatan Asli Daerah (PAD) merupakan sebuah komponen pembiayaan yang penting dalam pelaksanaan kegiatan pemerintahan daerah sebagai bagian dari implementasi desentralisasi fiskal. Salah satu sumber pendapatan yang besar untuk PAD adalah pajak daerah 
dimana saat ini pengaturaannya berdasarkan Undang-undang Nomor 28 tahun 2009. Peraturan ini merupakan perubahan dari undang-undang sebelumnya yang memiliki beberapa perbedaan dari undang-undang sebelumnya salah satunya adalah ditetapkannya kebijakan earmarking tax.

Earmarking tax merupakan kebijakan pengalokasian dana pajak yang digunakan untuk membiayai kegiatan-kegiatan yang berkaitan dengan pajak yang dipungut. jenis pajak yang termasuk dalam konsep ini adalah pajak kendaraan bermotor, pajak penerangan jalan dan pajak rokok. Dengan adanya pengalokasian dana tersebut maka akan tersedia jaminan untuk anggaran peningkatan kualitas pelayanan publik.

Pemenuhan pelayanan publik berlaku juga bagi pelaksanaan pemerintahan provinsi Sulawesi Utara (SULUT) mengingat semakin berkembangnya daerah ini dalam hal globalisasi dan moderenisasi termasuk pemasukan dana pajak kendaraan bermotor SULUT yang untuk tiap tahunnya bertambah, sehingga menggambarkan keadaan kendaraan bermotor di SULUT makin bertambah pula. Selain memberikan kontribusi baik bagi PAD SULUT, keadaan kendaraan bermotor ini juga menimbulkan hal buruk seperti kemacetan dan kerusakan jalan.

Pengaturan pajak daerah SULUT, Undang-undang Nomor 28 tahun 2009 dijabarkan kedalam Peraturan daerah SULUT Nomor 7 tahun 2011. Peraturan daerah ini memiliki kesamaan dengan undang-undang tersebut termasuk kebijakan earmarking tax-nya. Peraturan daerah ini diberlakukan sejak januari 2012.

Tujuan penelitian ini untuk menganalisis penerapan kebijakan earmarking tax pajak kendaraan bermotor di provinsi Sulawesi Utara sesuai dengan amanat dalam peraturan perundang-undangan yang berlaku.

\section{TINJAUAN PUSTAKA}

Waluyo (2011: 235) memaparkan bahwa secara resmi era otonomi daerah berlaku di Indonesia sejak 1 januari 2001. Sehingga daerah dituntut mencari berbagai alternatif sumber penerimaan yang dapat digunakan membiayai pengeluaran atau belanja daerah. Kebijakan ini merupakan penyelenggaraan pemerintahan dari yang sebelumnya bersifat terpusat menjadi terdesentralisasi.

Kerangka otonomi daerah dan desentralisasi fiskal telah memberikan dimensi yang lebih jelas bagi Daerah dalam menyelenggarakan pemerintahan dan pelayanan serta pengelolaan keuangan berdasarkan prinsip transparansi, partisipasi dan akuntabilitas. (Direktorat Jendral Perimbangan Keuangan Kementrian Keuangan RI, 2012: 13)

Undang-undang Nomor 28 tahun 2009 angka 10 menjelaskan bahwa pajak daerah, yang selanjutnya disebut pajak, adalah kontribusi wajib kepada daerah yang terutang oleh orang pribadi atau badan yang bersifat memaksa berdasarkan undang-undang, dengan tidak mendapatkan imbalan secara langsung dan digunakan untuk keperluan daerah bagi sebesarbesarnya kemakmuran rakyat. Pajak daerah dibagi atas Pajak provinsi dan pajak kabupaten kota.

Pengaturan mengenai pajak daerah dan retribusi daerah, diatur dalam Undang-undang Nomor 28 tahun 2009 yang merupakan perubahan dari Undang-undang Nomor 34 tahun 2000, memiliki beberapa perubahan, yang merupakan pokok pertimbangan pemerintah dalam menerapkan undang-undang yang sebelumnya. Pokok-pokok perubahannya yaitu 1) Penambahan jenis pajak daerah, 2) Perluasan basis pajak daerah dan retribusi daerah, 3) mengalihkan beberapa pajak pusat menjadi pajak daerah, 4) Kenaikan tarif maksimum pajak daerah, 5) Earmarking. 
Undang-undang Nomor 28 tahun 2009 meyatakan bahwa hasil pungutan pajak daerah tepatnya jenis pajak provinsi harus dibagi hasil dengan kabupaten/kota. Hal ini dilaksanakan dalam rangka pemerataan pembangunan dan peningkatan kemampuan keuangan kabupaten/kota dalam membiayai fungsi pelayanan kepada masyarakat, pajak provinsi dibagihasilkan kepada kabupaten/kota, dengan proporsi sebagai berikut:

Tabel 1. Proporsi Pembagian Dana Pajak antara Provinsi dengan Kabupaten/kota

\begin{tabular}{lcc}
\multicolumn{1}{c}{ Jenis Pajak } & Provinsi & Kab/kota \\
\hline Pajak Kendaraan Bermotor & $70 \%$ & $30 \%$ \\
Bea Balik Nama Kendaraan Bermotor & $70 \%$ & $30 \%$ \\
Pajak Bahan Bakar Kendaraan Bermotor & $30 \%$ & $70 \%$ \\
Pajak Air Permukaan & $50 \%$ & $50 \%$ \\
Pajak Rokok & $30 \%$ & $70 \%$ \\
\hline
\end{tabular}

Sumber: Undang-undang Nomor 28 tahun 2009

Michael (2012: 2), menyatakan Earmarking is the budgeting practice of dedicating tax or other revenues to a specific program or purpose. This practice typically involves depositing tax or other revenues into a special account from which the legislature appropriates money for the designated purpose. Kutipan ini memaparkan bahwa earmarking merupakan praktek penganggaran mendedikasikan pendapatan pajak atau pendapatan lainnya untuk program tertentu, dan praktek ini melibatkan penyetoran pajak atau pendapatan lainnya ke rekening khusus. Earmarking dimaksudkan untuk meningkatkan kualitas pelayanan secara bertahap dan terus menerus dan sekaligus menciptakan good governance dan clean government (Siahaan, 2010: 179).

Undang-undang Nomor 28 tahun 2009 tentang PDRD menyatakan bahwa Pajak Kendaraan Bermotor (PKB) adalah pajak atas kepemilikan dan/atau penguasaan kendaraan bermotor. Kendaraan bermotor adalah semua kendaraan beroda beserta gandengannya yang digunakan di semua jenis jalan darat, dan digerakkan oleh peralatan teknik berupa motor atau peralatan lainnya yang berfungsi untuk mengubah suatu sumber daya energi tertentu menjadi tenaga gerak kendaraan bermotor yang bersangkutan, termasuk alat-alat berat dan alat-alat besar yang dalam operasinya menggunakan roda dan motor dan tidak melekat secara permanen serta kendaraan bermotor yang dioperasikan di air. (UU No 28 thn 2009, Pasal 1, angka 12 dan $13)$.

\section{METODOLOGI PENELITIAN}

\subsection{Data}

Penelitian ini merupakan penelitian deskriptif dimana proses analisis dilakukan pada kebijakan yang berlaku dalam Undang-undang Nomor 28 tahun 2009 tentang Pajak Daerah dan Retribusi Daerah yang dijabarkan dalam Peraturan Daerah Sulawesi Utara Nomor 7 tahun 2011 tentang Pajak Daerah dimana didalamnya mengatur tentang kebijakan earmarking tax dan bagaimana pemberlakuannya di Provinsi Sulawesi Utara. Tempat penelitian yang dilakukan yaitu di Dinas Pendapatan Daerah Sulawesi Utara dan Dinas Pekerjaan Umum Sulawesi Utara serta waktu penelitian dilakukan kurang lebih 3 bulan yaitu bulan September sampai November 2015. 
Adapun langkah-langkah yang dilakukan dalam penelitian ini adalah:

1. Mengajukan Permohonan Penelitian

2. Disposisi Pimpinan Instansi

3. Pengumpulan Data

4. Analisis Data Penelitian dan Pembahasan

5. Menarik Kesimpulan

Data adalah sekumpulan fakta yang diperoleh melalui pengamatan (observasi) langsung atau survei (Indriantoro \& Supomo 2012: 10). Dalam penelitian ini menggunakan dua jenis data yaitu:

1. Data Kuantitatif adalah data penelitian berupa angka-angka atau numerik dan analisis menggunakan statistik.

2. Data Kualitatif adalah data yang disajikan secara deskriptif dan tidak dapat diukur dengan skala numerik.

Teknik pengumpulan data yang dilakukan adalah:

1. Penelitian Lapangan (field research), merupakan kegiatan kunjungan serta kegiatan pengumpulan data ditempat atau objek yang memiliki sumber data yang sesuai dengan penelitian, dan data diperoleh melalui cara wawancara dan documenter.

2. Penelitian Kepustakaan (library Research), merupakan cara pengumpulan yang dilakukan dengan mengumpulkan data dari teori-teori yang diperoleh dan dipelajari dari buku-buku, literatur, jurnal, serta bahan-bahan informasi lainnya yang berhungan dengan masalah yang diteliti untuk digunakan sebagai landasan pemikiran teoritis bagi penulis didalam membahas penelitian ini.

\subsection{Metode Analisis}

Dalam penelitian ini metode analisis yang digunakan adalah analisis deskriptif, merupakan langkah kerja untuk mendeskripsikan suatu objek, fenomena, atau setting social terjewantah dalam suatu tulisan yang bersifat naratif. Dalam menuangkan suatu tulisan, laporan penelitian kualitatif berisi kutipan-kutipan dari data/fakta yang diungkap di lapangan untuk memberikan ilustrasi yang utuh dan untuk memberikan dukungan terhadap apa yang disajikan. ( Satori \& Komariah, 2014 : 28)

\section{HASIL PENELITIAN DAN PEMBAHASAN}

\subsection{Hasil Penelitian}

Adanya kebijakan Earmarking tax di Indonesia ditandai dengan berlakunya Undangundang Nomor 28 tahun 2009 tentang Pajak Daerah dan Retribusi Daerah yang merupakan revisi dari undang-undang sebelumnya yang tercantum dalam pasal 8 ayat 5 untuk kebijakan alokasi dana Pajak Kendaraan Bermotor. Dengan besarannya diatur sebagai berikut:

Tabel 2 Pengalokasian (earmarked) beberapa jenis pajak yang diamanatkan dalam UU No. 28 tahun 2009 


\begin{tabular}{llll}
\hline $\begin{array}{c}\text { Jenis Pajak Daerah } \\
\text { yang di-earmark }\end{array}$ & Pasal, ayat & \multicolumn{1}{c}{$\begin{array}{c}\text { Besarnya } \\
\text { Alokasi }\end{array}$} & \multicolumn{1}{c}{ Tujuan Alokasi } \\
\hline $\begin{array}{l}\text { Pajak Kendaraan } \\
\text { Bermotor }\end{array}$ & Pasal 8, ayat 5 & Minimal 10\% & $\begin{array}{l}\text { Pembangunan dan/atau pemeliharaan jalan } \\
\text { Peningkatan moda dan sarana transportasi }\end{array}$ \\
Pajak Rokok & Pasal 31 & Minimal 50\% & $\begin{array}{l}\text { Mendanai pelayanan kesehatan masyarakat } \\
\text { Penegakan hukum oleh aparat yang } \\
\text { berwenang }\end{array}$ \\
Pajak Penerangan Jalan & Pasal 56, ayat 3 & Sebagian & Penyediaan penerangan jalan \\
\hline
\end{tabular}

Sumber: Undang-undang Nomor 28 tahun 2009

Tabel 2 menunjukan ketiga jenis pajak yang di-earmarked dengan besarannya masingmasing dan pengalokasiannya digunakan untuk membiayai pelayanan publik masing-masing pajak yang dipungut.

Pengalokasian dan pembagian dana pajak dari pungutan jenis pajak provinsi di SULUT, diatur dalam Peraturan Daerah Provinsi Sulawesi Utara (Perda) Nomor 7 tahun 2011 tentang Pajak Daerah. Peraturan daerah ini telah diberlakukan atau diterapkan sejak bulan januari tahun 2012. Dalam Perda sendiri pengaturan pengalokasian dan pembagian dana pajak kendaraan bermotor termuat pada:

1. BAB III, Bagian Kelima tentang Alokasi Dalam APBD, Pasal 14 yang mengatakan bahwa: "Hasil Penerimaan Pajak Kendaraan Bermotor paling sedikit dialokasikan 10\% (sepuluh persen) untuk meningkatkan sarana dan prasarana jalan serta peningkatan moda transportasi”.

2. BAB XII, Bagian Kesatu tentang Bagi Hasil dan Biaya Operasional, Pasal 67 ayat 1 mengatakan bahwa: "Hasil penerimaan Pajak Kendaraan Bermotor dan Bea Balik Nama Kendaraan Bermotor diserahkan kepada pemerintah kabupaten dan kota sebesar 30\% (tiga puluh persen)". Kemudian dalam Pasal 67 ayat 2 mengatakan bahwa: "pembagian sebagaimana dimaksud pada ayat 1 untuk pajak kendaraan bermotor dibagi sebesar 30\% (tiga puluh persen) berdasarkan pemerataan dan sebesar $70 \%$ (tujuh puluh persen) berdasarkan potensi”.

Melalui pengaturan tersebut maka dana pajak kendaraan bermotor yang telah dikumpulkan akan dibagihasilkan antara lain ke provinsi sebesar $70 \%$ dari jumlah dan ke kabupaten/kota sisanya yaitu sebesar 30\% dari jumlah. Pembagian 30\% tersebut selanjutnya dibagi ke 15 Kabupaten/kota berdasarkan pemerataan dan potensi masing- masing Kabupaten/kota. Namun sebelum dibagihasilkan masing-masing ke provinsi dan kabupaten/kota terlebih dahulu harus dipotong sebesar 3\% untuk pemungut pajak, hal ini telah diatur dalam ketentuan yang berlaku. Pemungutan pajak kendaraan bermotor dilakukan oleh masing-masing Unit Pelaksana Teknis Daerah (UPTD) yang terbagi di tiap Kabupaten/Kota, dimana penyetorannya dilakukan ke Bank Pembangunan Daerah dalam hal ini Bank SULUT.

Kegiatan pemasukan pendapatan dan pengeluaran untuk belanja SULUT diatur dalam rancangan APBD, dimana semua jenis pemasukkan pendapatan akan masuk dalam satu pot besar yaitu APBD, termasuk juga dana pajak kendaraan bermotor yang sudah dibagihasilkan, yaitu 70\% masuk ke kas daerah dalam APBD Provinsi dan 30\% akan dibagi lagi ke 15 kabupaten/kota yang nantinya akan masuk ke kas daerah kabupaten/kota dalam APBD atupun laporan keuangan masing-masing kabupaten/kota nantinya. Hal ini menunjukan bahwa dana 
pajak kendaraan bermotor yang masuk ke tiap kas daerah sudah tidak terlihat nominal yang sebenarnya, karena telah digabungkan secara keseluruhan dengan jumlah PAD yang diterima provinsi.

Dalam hal alokasi dana pajak kendaraan bermotor untuk meningkatkan sarana dan prasarana jalan serta peningkatan moda transportasi, yang mengatur belanja tersebut di SULUT adalah Dinas Pekerjaan Umum untuk peningkatan sarana jalan. Pengaturan rancangan anggaran untuk belanja tersebut diatur oleh masing-masing instansi ini dalam SKPD-nya. Sehingga dalam struktur APBD akan terlihat besaran nominal yang akan dikeluarkan untuk belanja peningkatan sarana jalan. Untuk membiayai belanja tersebut digunakanlah dana pendapatan yang sudah dirancangkan dalam APBD juga, dalam hal ini Badan Pengelola Keuangan dan Barang Milik Daerah SULUT akan menyetorkan dana ke masing-masing instansi untuk belanjannya. Pemasukan pendapatan asli daerah tahun 2014 dalam hal ini pajak kendaraan bermotor dapat dilihat dalam tabel berikut ini:

Tabel 3 Penerimaan PKB SULUT Tahun 2014

\begin{tabular}{|c|c|c|c|c|}
\hline No & Unit Kerja & Target TA. 2014 & Realisasi tahun 2014 & $\%$ dari target \\
\hline 1 & UPTD Manado & Rp 125.463.344.500 & Rp 116.684.761.443 & 93,00 \\
\hline 2 & UPTD Tondano & $\mathrm{Rp} \quad 14.981 .873 .288$ & Rp 16.873 .509 .370 & 112,63 \\
\hline 3 & UPTD Bitung & $\mathrm{Rp} \quad 24.165 .534 .000$ & Rp $\quad 24.063 .479 .725$ & 99,58 \\
\hline 4 & UPTD Tahuna & Rp $\quad 3.188 .339 .800$ & Rp $\quad 3.856 .579 .800$ & 120,96 \\
\hline 5 & UPTD Kotamobagu & Rp 12.046 .160 .500 & Rp 11.077.415.700 & 91,96 \\
\hline 6 & UPTD Amurang & $\mathrm{Rp} \quad 9.100 .149 .200$ & $\mathrm{Rp} \quad 10.633 .158 .800$ & 116,85 \\
\hline 7 & UPTD Airmadidi & Rp 21.548.211.000 & Rp 20.865 .045 .925 & 96,83 \\
\hline 8 & UPTD Tomohon & Rp 10.295 .479 .400 & Rp 10.142 .078 .900 & 98,51 \\
\hline 9 & UPTD Mitra & Rp $\quad 5.399 .449 .000$ & $\mathrm{Rp} \quad 4.876 .012 .250$ & 90,31 \\
\hline 10 & UPTD Bolmong & 8.855 .987 .800 & 7.834 .617 .100 & 88,47 \\
\hline 11 & UPTD Bolmut & $\mathrm{Rp} \quad 1.834 .512 .200$ & 1.910 .044 .800 & 104,12 \\
\hline 12 & UPTD Boltim & $\operatorname{Rp} \quad 2.881 .165 .500$ & 2.588 .154 .850 & 89,83 \\
\hline 13 & UPTD Bolsel & Rp $\quad 1.618 .087 .400$ & 1.301 .075 .100 & 80,41 \\
\hline 14 & UPTD Talaud & $\operatorname{Rp} \quad 1.216 .292 .000$ & 947.579 .000 & 77,91 \\
\hline \multirow[t]{2}{*}{15} & UPTD Sitaro & $\mathrm{Rp} \quad 1.355 .647 .000$ & 974.026 .000 & 71,85 \\
\hline & Jumlah & Rp 243.950.232.588 & Rp 234.627.538.763 & 96,18 \\
\hline
\end{tabular}

Sumber: Dinas Pendapatan Daerah Sulawesi Utara

Tabel 3 menunjukan bahwa penerimaan pajak kendaraan bermotor SULUT pada tahun 2014 adalah sebesar Rp 234.627.538.763 atau 96.18\% dari target untuk tahun anggaran 2014. Jumlah dana Pajak Kendaraan Bermotor yang diterima ini dibagikan ke kas Provinsi dan Kas Kabupaten/kota berdasarkan ketentuan yang berlaku.

Dana pajak kendaraan bermotor dibagi hasilkan untuk provinsi maupun Kabupaten/kota pada tiap bulan berjalan di tahun 2012. Nominal bagi hasil pajak kendaraan bermotor SULUT untuk tahun 2014 ditunjukan dalam rumusan berikut:

PKB tahun $2014 \quad:$ Rp 234.627.538.763

Untuk pemungut $\quad: 3 \% \times \operatorname{Rp} 234.627 .538 .763 \quad=\operatorname{Rp} 7.038 .826 .163$ 
Sisa yang akan dibagihasilkan ke Provinsi dan Kabupaten/Kota :

Rp 234.627.538.763 - Rp 7.038.826.163 = Rp 227.588.712.600

Provinsi $\quad: 70 \% \times \operatorname{Rp} 227.588 .712 .600 \quad=\mathrm{Rp} 159.312 .098 .820$

Kabupaten/Kota $\quad: 30 \% \times \mathrm{Rp} 227.588 .712 .600 \quad=\mathrm{Rp} \quad 68.276 .613 .780$

Terlihat bahwa dana bagi hasil pajak kendaraan bermotor yang masuk di kas daerah provinsi Sulawesi Utara untuk tahun 2014 adalah senilai Rp159.312.098.820 dalam kaitannya dengan konsep earmarking tax maka untuk melihat nilai minimum yang seharusnya dialokasikan akan dikalikan dengan 10\%:

Earmarking tax $\quad: 10 \% \times \mathrm{Rp} 159.312 .098 .820 \quad=\mathrm{Rp} 15.931 .209 .882$

Besaran alokasi sebesar Rp 15.931.209.882 tersebut merupakan nilai minimum yang menjadi patokan untuk dialokasikan dalam pembangunan sarana prasarana jalan dan moda transportasi, sehingga anggaran untuk belanja dalam hal pembangunan sarana transportasi harus bernilai minimal Rp 15.931.209.882 atau lebih. Dana bagi hasil pajak kendaraan bermotor tahun 2014 untuk kabupaten/kota sebesar Rp 68.276.613.780 akan dibagi ke 15 kabupaten kota sebesar 30\% (tiga puluh persen) berdasarkan pemerataan dan sebesar $70 \%$ (tujuh puluh persen) berdasarkan potensi.

Peningkatan sarana prasarana jalan di Provinsi Sulawesi Utara menjadi salah satu kegiatan belanja langsung yang diatur dalam rancangan APBD. Di Provinsi Sulawesi Utara sendiri yang mengatur urusan belanja langsung dalam hal peningkatan jalan ini adalah Dinas Pekerjaan Umum. Menurut wawancara yang dilakukan di Dinas Pekerjaan Umum Sulawesi Utara bersama Kepala Sub. Bagian Perencanaan dan Keuangan Bpk. Sinyo.J.P.Oflagi,SE,MAP, dikatakan bahwa di Dinas Pekerjaan Umum sendiri untuk sumber penerimaan dana yang masuk adalah berasal dari PAD, Dana Perimbangan, dan pendapatan lain yang sah yang semuanya berada di kas daerah yang dikelola oleh Badan Anggaran atau Badan Pengelola Keuangan dan Barang Milik Daerah SULUT. Dari sumber penerimaan tersebut diklasifikasikan untuk masing-masing pembelanjaan, dimana untuk belanja langsung dalam program pembanguan, rehabilitas dan pemeliharaan jalan di Provinsi Sulawesi Utara adalah bersumber dari dana perimbangan yaitu Dana Alokasi Khusus dan Dana Alokasi Umum, sedangkan untuk PAD sendiri lebih digunakan untuk pembiayaan Tunjangan Kerja Daerah (TKD). Hal ini telah ditetapkan berdasarkan ketentuan, diamana keberadaan PAD pun belum mampu membiaya program rehabilitas dan pemeliharaan jalan karna tingginya kebutuhan akan belanja tersebut, selain itu dalam hal pembelanjaan untuk program pembangunan dan rehabilitas jalan sendiri diserahkan kepada pihak ketiga dalam hal ini bersifat kontraktual. Berikut ini ditunjukan jumlah pengeluaran untuk pembangunan dan pemeliharaan jalan di Provinsi Sulawesi Utara tahun 2014:

Tabel 4 Pengeluaran untuk Belanja Pengadaan, Pemeliharaan dan Rehabilitas Jalan Provinsi Sulawesi Utara tahun 2014

\begin{tabular}{|c|c|c|c|c|}
\hline No & Uraian & Anggaran 2014 (Rp) & $\begin{array}{l}\text { Realisasi } 2014 \\
\text { (Rp) }\end{array}$ & $\%$ \\
\hline I & Belanja Pemeliharaan & 27.405.558.490,20 & 27.204.774.494,00 & 99,27 \\
\hline & Belanja Pemeliharaan Jalan & $27.405 .558 .490,20$ & 27.204.774.494,00 & 99,27 \\
\hline
\end{tabular}




\section{Belanja Modal Pengadaan}

Konstruksi Jalan

Belanja Modal Perencanaan Jalan
$168.640 .042 .824,99 \quad 127.654 .754 .525,00$

2.335.000.000,00

1.197.542.000,00

198.380.601.315,19

\section{TOTAL}

Sumber: Dinas Pekerjaan Umum Sulawesi Utara
75,70

51,29

Tabel 4.4 menunjukan jumlah anggaran dan realisasi untuk program pembangunan infrastruktur jalan di tahun 2014. Dan terlihat bahwa jumlah pengeluaran atau realisasi untuk belanja langsung dalam peningkatan sarana prasarana jalan di SULUT pada tahun 2014 adalah sebesar Rp. 156.057.071.019.

\subsection{Pembahasan}

Pajak kendaraan bermotor termasuk dalam pendapatan asli daerah yang dipungut dan dikumpulkan dananya oleh Dinas Pendapatan Daerah Sulawesi Utara.Pemungutan pajak kendaraan bermotor di Provinsi Sulawesi Utara mulai dari penyetoran pajak dari wajib pajak yang kemudian dananya dikumpulkan oleh masing-masing UPTD dan Dinas Pendapatan Daerah beserta dana pungutan pajak lainnya. Dana pungutan secara keseluruhan itupun akan dibagihasilkan antara kas provinsi dan kas kabupaten/kota untuk tiap bulan berjalan berdasarkan ketentuan. Dana pajak kendaraan bermotor masuk dalam kas daerah bersamaan dengan jenis pendapatan lainnya dalam bentuk pendapatan asli daerah melalui Dinas

Pendapatan Daerah yang kemudian pengelolaannya oleh Badan Pengelola Keuangan dan Barang Milik Daerah Provinsi Sulawesi Utara. Dana pajak kendaraan bermotor yang telah dipungut nantinya akan dibagikan untuk kas Provinsi dan Kabupaten/kota sebesar 70\% untuk kas daerah Provinsi dan 30\% untuk kas daerah kabupaten/kota, yang nantinya besaran 30\% tersebut akan dibagikan untuk 15 Kabupaten/kota yang memiliki UPTD dan pembagiannya berdasarkan pemerataan dan potensi masing-masing Kabupaten/kota. Dalam hal potensi pembagiannya diatur berdasarkan kemampuan tiap Kabupaten/kota dalam mengumpulkan Pajak Kendaraan Bermotor.

Tabel 5 Potensi Tiap Kabupaten Kota Melalui Realisasi Pajak Kendaraan Bermotor tahun 2014

\begin{tabular}{|c|c|c|c|c|c|}
\hline No & Unit Kerja & Target TA. 2014 & Realisasi tahun 2014 & $\%$ dari target & $\%$ potensi \\
\hline 1 & UPTD Manado & Rp 125.463.344.500 & Rp 116.684.761.443 & 93,00 & 49,73191 \\
\hline 2 & UPTD Tondano & $\mathrm{Rp} \quad 14.981 .873 .288$ & Rp $\quad 16.873 .509 .370$ & 112,63 & 7,19161 \\
\hline 3 & UPTD Bitung & $\mathrm{Rp} \quad 24.165 .534 .000$ & $\mathrm{Rp} \quad 24.063 .479 .725$ & 99,58 & 10,25603 \\
\hline 4 & UPTD Tahuna & $\mathrm{Rp} \quad 3.188 .339 .800$ & $\mathrm{Rp} \quad 3.856 .579 .800$ & 120,96 & 1,64370 \\
\hline 5 & UPTD Kotamobagu & $\mathrm{Rp} \quad 12.046 .160 .500$ & $\mathrm{Rp} \quad 11.077 .415 .700$ & 91,96 & 4,72127 \\
\hline 6 & UPTD Amurang & $\mathrm{Rp} \quad 9.100 .149 .200$ & $\mathrm{Rp} \quad 10.633 .158 .800$ & 116,85 & 4,53193 \\
\hline 7 & UPTD Airmadidi & $\mathrm{Rp} \quad 21.548 .211 .000$ & Rp 20.865 .045 .925 & 96,83 & 8,89283 \\
\hline
\end{tabular}




\begin{tabular}{|c|c|c|c|c|c|c|c|}
\hline 8 & UPTD Tomohon & $\mathrm{Rp}$ & 10.295 .479 .400 & $\mathrm{Rp}$ & 10.142 .078 .900 & 98,51 & 4,322629 \\
\hline 9 & UPTD Mitra & $\mathrm{Rp}$ & 5.399 .449 .000 & $\mathrm{Rp}$ & 4.876 .012 .250 & 90,31 & 2,07819 \\
\hline 10 & UPTD Bolmong & $\mathrm{Rp}$ & 8.855 .987 .800 & $\mathrm{Rp}$ & 7.834.617.100 & 88,47 & 3,339172 \\
\hline 11 & UPTD Bolmut & $\mathrm{Rp}$ & 1.834 .512 .200 & $\mathrm{Rp}$ & 1.910 .044 .800 & 104,12 & 0,81407 \\
\hline 12 & UPTD Boltim & $\mathrm{Rp}$ & 2.881 .165 .500 & $\mathrm{Rp}$ & 2.588 .154 .850 & 89,83 & 1,10309 \\
\hline 13 & UPTD Bolsel & $\mathrm{Rp}$ & 1.618 .087 .400 & $\mathrm{Rp}$ & 1.301.075.100 & 80,41 & 0,55452 \\
\hline 14 & UPTD Talaud & $\mathrm{Rp}$ & 1.216.292.000 & $\mathrm{Rp}$ & 947.579 .000 & 77,91 & 0,40386 \\
\hline \multirow[t]{2}{*}{15} & UPTD Sitaro & $\mathrm{Rp}$ & 1.355 .647 .000 & $\mathrm{Rp}$ & 974.026 .000 & 71,85 & 0,41513 \\
\hline & Jumlah & $\mathrm{Rp} 2$ & 243.950 .232 .588 & $\mathrm{Rp} 2$ & 234.627 .538 .763 & 96,18 & 100 \\
\hline
\end{tabular}

Sumber: Dinas Pendapatan Daerah Sulawesi Utara

Tabel 5 Menunjukan jumlah potensi tiap Kabupaten/kota yang nantinya akan digunakan sebagai acuan untuk pembagian dana Pajak Kendaraan Bermotor untuk tiap Kabupaten/kota.

Sistem APBD SULUT dalam rangka pelaksanaan kegiatan pemerintahan untuk pelayanan publik menggambarkan suatu sistem yang bersifat terarah dalam penganggaran, penyetoran dana serta pembelanjaannya. Tidak ada spesifikasi pengaturan dana dari pendapatan tertentu akan di khususkan untuk pengeluaran tertentu, artinya bahwa semua jenis pendapatan asli daerah akan masuk secara keseluruhan ke kas daerah dan penyetoran dana untuk kegiatan belanja daerah ditransfer berdasarkan jumlah dalam rancangan APBD ataupun kebutuhan daerah yang disepakati berdasarkan peraturan. Hal ini menunjukan bahwa nilai minimal $10 \%$ yang harus dialokasikan dananya untuk sarana dan prasarana transportasi tidak akan terlihat, karena dana pajak kendaraan bermotor ini di setorkan ke kas daerah secara keseluruhan.

Keberadaan besaran minimal 10\% ini yang diatur juga dalam Perda No 7 tahun 2011 dijadikan sebagai jaminan bagi ketersediaan dana untuk peningkatan sarana dan prasarana transportasi di SULUT. Namun pembiayaan untuk pengeluaran tersebut juga didasarkan atas keperluan dari daerah, jadi dengan kata lain jumlah pengeluarannya bisa lebih dari besaran 10\% dari dana Pajak Kendaraan Bermotor tersebut. Selan itu di Provinsi Sulawesi Utara sendiri untuk pembangunan jalan sebagian besar didanai atau bersumber dari Dana Alokasi Khusus dan Dana Alokasi Umum, memngingat besarnya kebutuhan dana yang diperlukan bagi pembangunan infrastruktur ini sedangka untuk PAD sendiri pengeluarannya lebih banyak untuk pembiayaan Tunjangan Kinerja Daerah (TKD).

Melalui hasil penelitian diatas, ditunjukkan jumlah realisasi penerimaan dan bagi hasil pajak kendaraan bermotor serta jumlah belanja dalam peningkatan jalan di Sulawesi Utara pada tahun 2014. Maka dapat dilihat kaitannya dengan kebijakan earmarking tax yang dirangkumkan kedalam tabel berikut ini:

Tabel 6 Penerimaan PKB dan belanja untuk sarana prasarana jalan SULUT 2014

$\begin{array}{cccc}\text { Penerimaan PKB keseluruhan } & \text { Bagi Hasil ke } & \text { Earmarking tax } & \text { Pengeluaran untuk sarana } \\ \text { Provinsi 70\% } & \text { minimal 10\% } & \text { prasarana jalan }\end{array}$




\section{Sumber: Dispenda dan Dinas PU SULUT}

Tabel 6 menunjukan gambaran perbandingan antara penerimaan Pajak Kendaraan Bermotor yang telah dibagi hasilkan bersama besaran alokasi dana sesesar $10 \%$ dengan jumlah pengeluaran untuk belanja modal infrastruktur jalan. Jumlah dana alokasi (earmarking tax) adalah senilai Rp 15.931.209.882 sedangkan jumlah untuk belanja modal pembangunan dan pemeliharaan jalan adalah senilai Rp.156.057.071.019. Dengan demikian terlihat bahwa jumlah dana alokasi senilai Rp.15.931.209.882 tersebut sangatlah kecil jika dibandingkan dengan pengeluaran untuk belanja modal tersebut dimana hanya mencapai 10,2\% dari biaya tersebut. Sedangkan pengeluaran untuk belanja modal tersebut mencapai 97,96\% dari jumlah penerimaan Pajak Kendaraan Bermotor yang dibagihasilkan ke kas Provinsi Sulawesi Utara.

Menurut analisis dan hasil wawancara yang dilakukan peneliti di beberapa instansi dan narasumber, maka dapat ditemukan beberapa kendala dalam penerapan kebijakan earmarking tax terhadap Pajak Kendaraan Bermotor ini yaitu:

1. Kurangnya sosialisasi mengenai Peraturan Daerah Sulawesi Utara No. 7 tahun 2011 mengenai Pajak Daerah

2. Kurangnya komunikasi antar SKPD yang terkait, bilamana ada peraturan mengenai earmarking tax ini atau adanya perkembangan dan perubahan peraturan yang ada.

3. Semua pendapatan termasuk PAD yang masuk menjadi satu ke kas daerah ke dalam APBD dan tidak ada alokasi khusus untuk pembiayaan untuk biaya tertentu yang dibagi-bagikan.

4. PAD sendiri pembiayaannya lebih banyak dikhususkan untuk Tunjangan Kinerja Daerah (TKD)

5. Sistem penerapan earmarking tax atau SOP nya yang masih belum jelas

6. Jumlah presentase alokasi dana untuk earmarking tax sebesar $10 \%$ terlalu kecil jika dibandingkan dengan tujuan pengeluarannya.

\section{PENUTUP}

\subsection{Kesimpulan}

Berdasarkan uraian-uraian dari bab sebelumnya termasuk hasil penelitian dan pembahasan, maka dapat disimpulkan bahwa kebijakan earmarking tax pada Pajak Kendaraan Bermotor di Provinsi Sulawesi Utara berdasarkan Undang-undang Nomor 28 tahun 2009 dan Peraturan Daerah Provinsi Nomor 7 tahun 2011 belum dapat diterapkan sepenuhnya untuk pembangunan dan pemeliharaan infrastruktur jalan di Provinsi Sulawesi Utara. Pemerintah Provinsi Sulawesi Utara belum memiliki sistem pembukuan dalam hal pembagian atau pengalokasian penerimaan Pajak Kendaraan Bermotor untuk pengeluaran tertentu, sehingga pengalokasian dana pajak tersebut untuk pembangunaan dan pemeliharaan jalan tidak terlihat dengan jelas.

Selain itu dapat dikatakan bahwa kebijakan earmarking tax pada Pajak Kendaraan Bermotor ini tidak dapat menutupi kebutuhan pembiayaan pembangunan dan pemeliharaan jalan di Provinsi Sulawesi Utara dikarenakan besarnya presentase belanja untuk pebiayaan tersebut dengan presentase alokasi dana PKB yang hanya sebesar 10\% saja, sehingga dana ini hanya dijadikan sebagai jaminan untuk ketersediaan dana. Pada tahun 2014 Provinsi Sulawesi Utara mengeluarkan dana untuk Pembangunan dan Pemeliharaan jalan sebesar Rp156.057.071.019 sedangkan untuk alokasi dana dari PKB yang diperuntukkan bagi 
pengeluaran ini adalah Rp.15.931.209.882 atau 10,2\% dari pengeluaran yang dikeluarkan Provins Sulawesi Utara untuk Pembangunan dan Pemeliharaan Jalan.

\subsection{Saran}

Berdasarkan kesimpulan yang ada maka dapat disarankan yaitu:

1. Perlu adanya Standar Operasional Prosedur (SOP) untuk penerapan kebijakan earmarking tax ini, sehingga dapat dikontrol sebagaimana mestinya. Bila perlu dibuat akun khusus untuk kebijakan alokasi ini agar dapat mempermudah penerapannya.

2. Perlu adanya sosialisasi dari pemerintah kepada pihak-pihak yang berkaitan dengan kebijakan ini, mengingat kebijakan ini memerlukan persiapan sebelum diterapkan

3. Peningkatan terhadap komunikasi dan koordinasi antara pihak-pihak atau instansi terkait, sehingga dapat mengikuti perkembangan peraturan atau ketentuan-ketentuan baru yang berlaku

4. Berkaitan dengan kebijakan ini telah diterapkan dalam undang-undang dan perda, maka perlu di spesifikasikan penerimaan khusus yang dialokasikan jumlahnya dan digunakan untuk pembiayaan apa, sehingga lebih jelas peruntukan dan penggunaan dananya dan tidak sia-sia peraturan yang telah ditetapkan tersebut.

\section{DAFTAR PUSTAKA}

Siahaan Marihot Pahala. 2010. Pajak Daerah dan Retribusi Daerah. Edisi revisi, Rajawali pers : Jakarta.

Indriantoro, Supomo, 2012. Metode Penelitian Bisnis untuk Akuntansi dan Manajemen.

Edisi Pertama. BPFE-Yogyakarta : Yogyakarta.

Sugiyono, 2010. Metode Penelitian Bisnis. Alfabeta : Bandung

Michael Joel, 2012. Earmarking State Tax Revenues. Policy Brief Research Department Minnesota House of Representatives : St. Paul.

Carling Robert, 2007, Tax Earmarking Is It Good Practice?. The Centre for Independent Studies : St Leonard Australia.

Bela Poetri Mutiara (2010), “Analisis Earmarking Tax Atas Pajak Kendaraan Bermotor (Studi Earmarking Tax di DKI J akarta)" : Universitas Indonesia, Depok.

Setyani Murdiyana (2012), “Analisis Penerimaan Pajak Kendaraan Bermotor dan

Kontribusi Terhadap Pendapatan Asli Daerah (PAD) Provinsi Sulawesi Utara" : Universitas Sam Ratulangi, Manado.

Fitriastuti Septi Mulia (2014), "Studi Penerapan E armarking Tax Pajak Kendraan B ermotor Terkait Pemeliharaan J alan di Kabupaten XXX Provinsi J awa Timur". Universitas Brawijaya, Malang.

Waluyo, 2011. Perpajakan Indonesia. edisi 10. Salemba Empat : Jakarta

Kementrian Keuangan Republik Indonesia, 2012. Pelengkap Buku Pegangan Penyelenggaraan Pemerintahan dan Pembangunan Daerah : Jakarta. 
Dinas Pendapatan Daerah Sulawesi Utara. 2014. Profil 2014 Dinas Pendapatan Daerah Sulawesi Utara. Manado

Undang-undang Republik Indonesia Nomor 23 Tahun 2014 tentang Pemerintahan Daerah.2014.Jakarta

Undang-undang Republik Indonesia Nomor 33 Tahun 2004 tentang Perimbangan Jeuangan Pemerintah Pusat dan Daerah. 2004.Jakarta

Undang-Undang Republik Indonesia Nomor 28 Tahun 2009 tentang Pajak Daerah dan Retribusi Daerah (PDRD). 2009. Jakarta

Peraturan Daerah (PERDA) Provinsi Sulawesi Utara Nomor 7 Tahun 2011 Tentang Pajak Daerah. 2011.Manado 